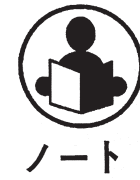

ノート

\title{
塩化物イオンを含むホウ酸塩緩衝溶液中における 鉄不動態皮膜破壊に及ぼすヨウ化物イオンの影響*
}

\author{
荒牧國次 ${ }^{* *}$ \\ ** 慶應義塾大学名誉教授
}

\author{
The Effect of Iodide Ion on Passive Film Breakdown \\ of Iron in a Borate Buffer Containing Chloride Ion* \\ Kunitsugu Aramaki ** \\ ** Professor Emeritus, Keio University
}

\begin{abstract}
Recently, passive film breakdown of $\mathrm{Fe}$ has been investigated in solutions of various anions by measuring the time required for breakdown, $t_{\mathrm{bd}}$ and permeation of anions into the passive film using X-ray photoelectron spectroscopy. The results have been discussed on the basis of the hard and soft acids and bases (HSAB) principle. In previous study, the pitting and repassivation potentials of a passivated Fe electrode were measured in a borate buffer solution containing $\mathrm{Cl}^{-}$. The effects of added $\mathrm{I}^{-}$on pit initiation and growth were discussed using electronprobe microanalysis and based on the HSAB principle. In this paper, the results of the previous investigation are interpreted by considerations of the recent work in more detail.
\end{abstract}

Key words : iron, passive film breakdown, pitting potential, repassivation potential, chloride ion, iodide ion, electron-probe microanalysis

\section{1. 緒言}

pH8.49 のホウ酸塩緩衝溶液中でアノード分極によっ て不動態化した Fe 電極を $0.1 \mathrm{M}\left(\right.$ moldm $\left.^{-3}\right)$ の種々の陰 イオン溶液中に浸漬し, 自然浸漬電位 $E_{\mathrm{oc}}$ の追跡から不 動態皮膜破壊までの時間 $t_{\mathrm{bd}}$ を求めた ${ }^{1)}$ 。ささら，不動態 皮膜中への $\mathrm{Cl}^{-}$と $\mathrm{I}^{-}$の侵入を $\mathrm{X}$ 線光電子分光法 $(\mathrm{XPS})$ に よって調べ2)，その結果を硬いおよび軟らかい酸塩基の 法則 (HSAB 則 $)^{3)-6)}$ に基づいて考察した ${ }^{2)}$ 。これらの陰イ オンのピット発生に及ぼす影響はピット発生の前兆現象 として生成する準安定ピット内における裸の Fe 表面の 腐食速度と関係し, $\mathrm{Fe}$ 表面の腐食を抑制する $\mathrm{I}^{-}$ではピ ット発生が抑制され，あまり抑制しない $\mathrm{Cl}^{-}$ではピット を発生しやすいと考察した2).

以前に行った実験において，不動態化した Fe 電極を $0.01 \mathrm{M}$ の $\mathrm{Cl}^{-}$または $\mathrm{I}^{-}$を含む $\mathrm{pH} 8.49$ のホウ酸塩緩衝溶 液中におけるアノード分極測定から孔食電位 $E_{\mathrm{pit}}$ を評価 した結果, $\mathrm{I}^{-}$の添加よりも $\mathrm{Cl}^{-}$の添加が $E_{\mathrm{pit}}$ を低下させ たことから, $\mathrm{Cl}^{-}$のほうが不動態皮膜を破壊しやすく, $t_{\mathrm{bd}}$ の結果と一致することが確かめられた ${ }^{7)}$.さらに別の 実験において，0.05 M の $\mathrm{Cl}^{-}$を含む同じホウ酸塩緩衝溶 液中に拈ける不動態化 $\mathrm{Fe}$ 電極の $E_{\mathrm{pit}}$ と再不動態化電位 $E_{\text {rep }}$ を測定し，それぞれ不動態皮膜におけるピット発生 とピット成長の尺度として用い，種々のインヒビターを 添加したときのピット発生とピット成長に対する抑制効 果を評価した8). その中で $0.03 \mathrm{M}$ の $\mathrm{I}^{-}$を添加した場合, $E_{\mathrm{pit}}$ については抑制効果が見られなかったのに対して $E_{\mathrm{rep}}$

* 第 61 回材料と環境討論会 (米子, 2014 年)で発表

** ₹ 158-0083 東京都世田谷区奥沢 2-23-26(2-23-26, Okusawa, Setagayaku, Tokyo, 158-0083 Japan)
には抑制効果が見られた。 HSAB 則に従えば，ピット発 生前の $\mathrm{Fe}$ 不動態皮膜中に存在する $\mathrm{Fe}^{3+}$ が硬い酸である ために，軟らかい塩基に分類される I-が作用できず，ピ ット発生に抑制効果がないと言える。 ピット発生後のピ ット成長段階ではピット内の $\mathrm{pH}$ 低下によって裸の $\mathrm{Fe}$ 表面(軟らかい酸)が現れ， I が表面に吸着してピット内 の腐食を抑制するために，ピット成長が抑制されると考 察した ${ }^{8)}$ 。このときの $E_{\text {rep }}$ におけるピット部分を含む表 面の走査電子顕微鏡 $(\mathrm{SEM})$ 写真とピット部を通る電子線 プローブ微小分析法(EPMA)の結果から，ピット内の裸 の $\mathrm{Fe}$ 表面における $\mathrm{I}^{-}$の吸着と $\mathrm{Cl}^{-}$の脱着によってピッ ト成長が抑制されたものと結論した ${ }^{8)}$.

以前の研究では, Pearsonの分類に従って $\mathrm{Cl}^{-}$を硬い 塩基に分類していたが，最近の研究では，軟らかい塩基 に分類することでピット発生を説明した。この分類の違 いが現象の説明に整合することを確認する必要がある. また, 以前の研究では $\mathrm{I}^{-}$が軟らかい塩基であって $\mathrm{Fe}^{3+}$ (硬い酸)に作用できないために，ピット発生を抑制でき ないとしたが， $E_{\text {pit }}$ から見ればピット発生を促進してい る。この現象の説明も必要である. 本報では, 最近の研 究における考察と以前の研究結果との整合性を考え，以 前の研究において説明されなかった現象の検討を試みる ことにする.

\section{2. 実験}

\section{1 材料}

ここで示す実験は文献 8) に示されたものである. 99.99\% Fe 丸棒(Johnson Matthey Chemicals 社製，直径 $5 \mathrm{~mm}$ )をテフロンに埋め込み，円形の断面を分極測定用 の電極として用いた。 $99.99 \% \mathrm{Fe}$ 円板 (Nilaco 社製，直 径 $10 \mathrm{~mm}$ ，厚さ $0.5 \mathrm{~mm}$ ) をガラス管の先端にテフロン収 
縮チューブで固定して，EPMA用の電極とした．表面を

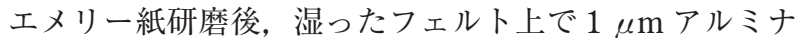
粉を用いて研磨した．水中次いでアセトン中で超音波洗 浄し，水洗後直ちに用いた。

$\mathrm{pH} 8.49$ のホウ酸塩緩衝溶液は $0.15 \mathrm{M}$ の $\mathrm{H}_{3} \mathrm{BO}_{3}$ と $0.035 \mathrm{M}$ の $\mathrm{Na}_{2} \mathrm{~B}_{4} \mathrm{O}_{7}$ により調製した。 $0.05 \mathrm{M}$ の NaCl を ホウ酸塩緩衝溶液に添加した。また，この溶液にインヒ ビターとして $0.03 \mathrm{M}$ の KI を添加した。試薬はいずれも 特級試薬で, 再蒸留水に溶解した。

\section{2 アノード分極測定}

丸棒電極をホウ酸塩緩衝溶液中 $30^{\circ} \mathrm{C},-0.98 \mathrm{~V}$ vs. $\mathrm{SCE}$ (飽和カロメル電極)において $1 \mathrm{~h}$ 定電位カソード還 元した後 ${ }^{9)}$, 大気開放ホウ酸塩緩衝溶液中 $30^{\circ} \mathrm{C}$ において $E_{\text {oc }}$ から $0.80 \mathrm{~V}$ vs. $\mathrm{SCE}$ まで $1 \mathrm{mVs}^{-1}$ の速度で電位走査 して $\mathrm{Fe}$ 表面を不動態化した。次にこの電極を大気開放 $0.05 \mathrm{M} \mathrm{Cl}^{-}$を含むホウ酸塩緩衝溶液中あるいはさらに $0.03 \mathrm{M} \mathrm{I}^{-}$を添加した溶液中 $30^{\circ} \mathrm{C}$ において $E_{\mathrm{oc}}$ から 1 $\mathrm{mVs}^{-1}$ の速度で正方向に走査し, 急激な電流密度 $i$ の増 加で示されるピット発生の起点から $E_{\mathrm{pit}}$ を求めた． $i$ が $10 \mu \mathrm{Acm}^{-2}$ に到達したときに走査方向を逆転させ，負方 向に同じ速度で走査した。 ピット発生後はアノード溶解 によって $i$ は増加した後に，不動態皮膜の再生によって

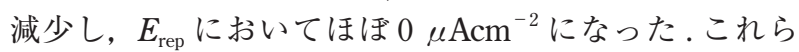
のアノード分極曲線が Fig. 1 に示されている.

\section{3 電子線プローブ微小分析法 (EPMA)}

同様に研磨し洗浄した円板電極をホウ酸塩緩衝溶液中

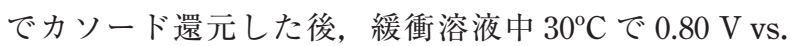
$\mathrm{SCE}$ まで $1 \mathrm{mVs}^{-1}$ の速度で走査し不動態化した。この電

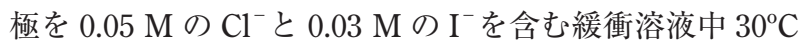
において $1 \mathrm{mVs}^{-1}$ の速度で $E_{\mathrm{oc}}$ より正方向に走査し， $E_{\mathrm{pit}}$

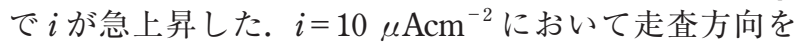
逆転し, 前と同様に $E_{\text {rep }}$ において $i$ がほ $0 \mu \mathrm{Acm}^{-2} に$ なった，直ちに水洗し，円板電極をガラス管から外した 後, 真空乾燥した。

円板電極表面を Shimadzu EPMA-8705 分析器により分 析した．表面の SEM 写真像観察後，ピット部を通る直 線上における組成 $\mathrm{Fe}, \mathrm{Cl}, \mathrm{I}$ の X 線強度を測定した。

\section{3. 結果と考察}

\section{$3.1 \mathrm{Cl}^{-}$による $\mathrm{Fe}$ 不動態皮膜におけるピット発生お よびピット成長}

Fig. 1 に $0.05 \mathrm{M} \mathrm{Cl}^{-}$を含む $\mathrm{pH} 8.49$ のホウ酸塩緩衝溶 液中における不動態化 $\mathrm{Fe}$ 電極の動電位アノード分極曲 線(曲線 $\mathrm{A}, \mathrm{a} \sim \mathrm{e}$ ) を示す．不動態皮膜の存在を示す高い $E_{\text {ос }}(\mathrm{a}$ 点) より正方向の電位走査とともに $i$ は徐々に増加 した. 上向きの小さい $i$ の振動(電流スパイク)が多数現 れ，不動態皮膜破壊の前兆現象を示した。 b 点において $i$ は急激に増加し, ピットが発生した。 b 点の電位が孔 食電位で, この場合はインヒビター無添加であるので $E_{\mathrm{pit}}{ }^{0}$ とする。

$i$ が $10 \mu \mathrm{Acm}^{-2}$ に達したときに走査方向を反対に切り 替えると (c 点), $i$ は急速に増大した. Fig. 1 の縦軸のス ケールを 100 倍に変えてある。これはピット発生後のピ

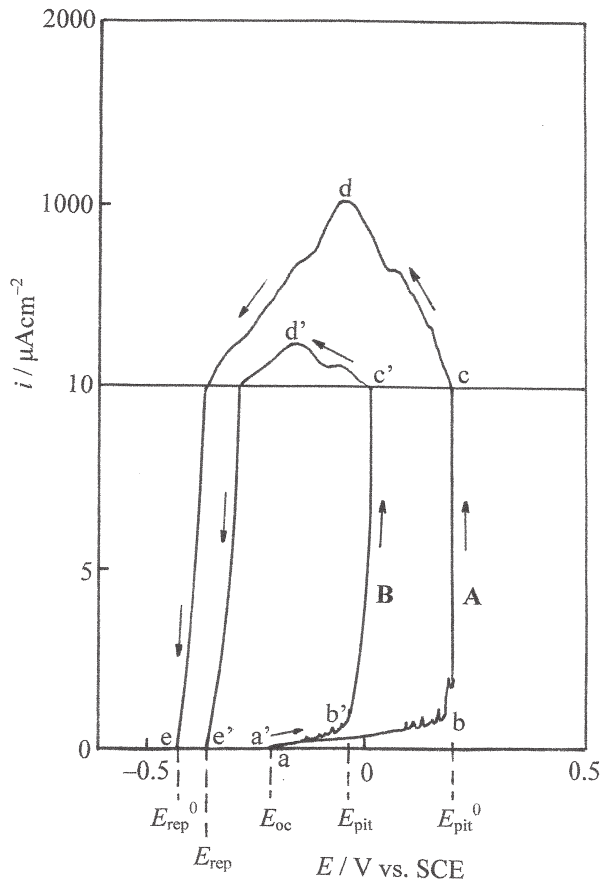

Fig. 1 Examples of anodic polarization curves (the potential, $E$ and current density, $i$ ) for a passivated $\mathrm{Fe}$ electrode in borate buffer solutions containing $0.05 \mathrm{M} \mathrm{Cl}^{-}$(curve A, a $\sim \mathrm{e}$ ) and $0.05 \mathrm{M} \mathrm{Cl}^{-}$plus $0.03 \mathrm{M} \mathrm{I}^{-}$(curve $\mathrm{B}, \mathrm{a}^{\prime} \sim \mathrm{e}^{\prime}$ ). The potential sweep was reversed at $i=10 \mu \mathrm{Acm}^{-2}$ (c and $\left.\mathrm{c}^{\prime}\right)$. The open-circuit potential, pitting potentials and repassivation potentials in the absence and presence of $\mathrm{I}^{-}$ are indicated with $E_{\text {oc }}, E_{\text {pit }}{ }^{0}, E_{\text {pit }}, E_{\text {rep }}{ }^{0}$ and $E_{\text {rep }}$, respectively.

ット内で溶解した $\mathrm{Fe}^{3+} や \mathrm{Fe}^{2+}$ が加水分解して $\mathrm{H}^{+}$を発生 L,

$$
\begin{aligned}
& \mathrm{Fe}^{3+}+\mathrm{H}_{2} \mathrm{O} \rightarrow(\mathrm{FeOH})^{2+}+\mathrm{H}^{+} \\
& \mathrm{Fe}^{2+}+\mathrm{H}_{2} \mathrm{O} \rightarrow(\mathrm{FeOH})^{+}+\mathrm{H}^{+}
\end{aligned}
$$

ピット内の水溶液を酸性にし, 生成した裸の $\mathrm{Fe}$ 表面が 高いアノード分極によってアノード反応

$$
\mathrm{Fe} \rightarrow \mathrm{Fe}^{2+}+2 \mathrm{e}^{-} \rightarrow \mathrm{Fe}^{3+}+3 \mathrm{e}^{-}
$$

が起こるためである .

しかし, ピット内部の溶液が交換し, ホウ酸塩, $\mathrm{O}_{2}$, $\mathrm{H}_{2} \mathrm{O}$ がピット内に入って来ると $\mathrm{pH}$ は上昇し, ピット内 が再び不動態化される。このため $i$ は $\mathrm{d}$ 点でピークを描 き $E$ の低下とともに $i$ は減少し, e 点において $i$ はほほ 0 $\mu \mathrm{Acm}^{-2}$ になった，e点の電位が再不動態化電位で，イ ンヒビター無添加であるので $E_{\mathrm{rep}}{ }^{0}$ とする． $E_{\mathrm{pit}}{ }^{0}$ がピット 発生の標準值 (ブランク), $E_{\mathrm{rep}}{ }^{0}$ がピット成長の標準值で あり，いずれもインヒビターの添加がこれらの值を正方 向に移動させればピット発生，ピット成長を抑制したこ とになる。

\section{2 「`を添加した時のピット発生とピット成長に及ぼ す影響}

$0.05 \mathrm{M}$ の $\mathrm{Cl}^{-}$を含むホウ酸塩緩衝溶液に $0.03 \mathrm{M}$ の $\mathrm{I}^{-}$ をインヒビターとして添加したときの不動態化 Fe 電極 のアノード分極曲線を Fig. 1 の曲線 B ( $\left.\mathrm{a}^{\prime} \sim \mathrm{e}^{\prime}\right)$ に示す. $E_{\mathrm{oc}}\left(\mathrm{a}\right.$ 点) は $\mathrm{a}$ 点とほとんど同じであったが, $E_{\mathrm{pit}}(\mathrm{b}$ 点) に おいてピットが発生し, $i$ は急激に増加した. $E_{\mathrm{pit}}{ }^{0}>E_{\mathrm{pit}}$ であるので， $\mathrm{I}^{-}$の添加によってピット発生が促進された 
ことになる．以前の研究8)においては, 不動態皮膜中の $\mathrm{Fe}^{3+}$ が硬い酸に分類され，軟らかい塩基である $\mathrm{I}^{-}$が安定 な酸塩基結合を作れないために, Pearsonの分類 ${ }^{3)} に$ 従

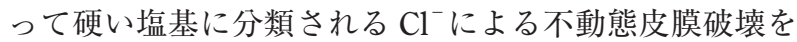
抑制できないので, $E_{\text {pit }}{ }^{0}>E_{\text {pit }}$ であると説明した. 一方, オクチルチオプロピオン酸イオン $\mathrm{C}_{8} \mathrm{H}_{17} \mathrm{~S}\left(\mathrm{CH}_{2}\right)_{2} \mathrm{CO}_{2}{ }^{-}$や オレイン酸イオン $\mathrm{C}_{17} \mathrm{H}_{33} \mathrm{CO}_{2}{ }^{-}$のような硬い塩基の沈殿イ ンヒビターは $\mathrm{Fe}^{3+}$ と安定な結合を作って不動態皮膜の欠 陥部に沈殿し, 破壊を抑制するために $E_{\mathrm{pit}}{ }^{0}<E_{\mathrm{pit}}$ である と結論した ${ }^{10)}$.

最近の研究では $\mathrm{I}^{-} や \mathrm{Cl}^{-}$は軟らかい塩基に分類され,

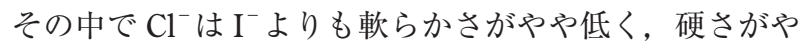

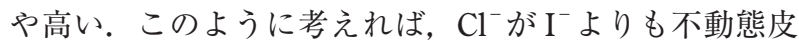
膜を破壊しやすいことに矛盾しない。これによって，ほ かの硬い塩基の陰イオンたとえば $\mathrm{F}^{-}$や $\mathrm{CH}_{3} \mathrm{CO}_{2}{ }^{-}$が不動 態皮膜に侵入しにくく, ピットを発生させにくいことと 区別できる． $\mathrm{I}^{-}$や $\mathrm{Cl}^{-}$は不動態皮膜中の $\mathrm{Fe}^{3+}$ によって拘 束されず，皮膜内部に侵入しやすいことがXPSによっ

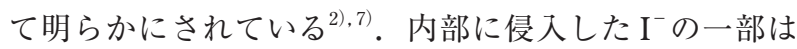
破壞の前兆現象として生成する準安定ピット内の腐食を 抑制するが，一部は不動態皮膜を溶解して破壊を促進す $ろ^{1)}$. 多くの陰イオンの中で，軟らかい塩基に属する $\mathrm{I}^{-}$ や $\mathrm{Cl}^{-}$は硬い塩基に分類される陰イオンよりも破壊を促 進する ${ }^{1), 7)}$ 。たとえば，侵食性陰イオンとして扱われて いる $\mathrm{SO}_{4}{ }^{2-} よ り も \mathrm{I}^{-} や \mathrm{Cl}^{-}$は $\mathrm{Fe}$ 不動態皮膜を破壊しや すい"1). Fig. 1 において, $E_{\text {pit }}{ }^{0}>E_{\text {pit }}$ であることは $\mathrm{I}^{-}$が破 壊を促進することを明らかに示している。

非常に硬い酸である $\mathrm{Fe}^{3+}$ は非常に軟らかい $\mathrm{I}^{-}$と安定 な結合を作りにくい。普通の状態では $\mathrm{FeI}_{3}$ は存在しな い ${ }^{11)}$ 。しかし, $\mathrm{Fe}^{3+}-\mathrm{O}^{2-}$ 結合によって生成した $\mathrm{Fe}$ 不動 態皮膜を破壊するには I-によってこの結合を切らねばな らない。一つの可能なプロセスとして, $\mathrm{Fe}^{3+}$ と $\mathrm{I}^{-}$が酸化 還元反応を起こすことが予想される． $\mathrm{Fe}^{3+}$ は酸化性があ り， I'は還元性があるので,

$2 \mathrm{Fe}^{3+}+3 \mathrm{I}^{-} \rightarrow 2 \mathrm{Fe}^{2+}+\mathrm{I}_{3}$

の反応が起こり得る。この反応は無水メタノール中で確 認されている ${ }^{12)} \cdot \mathrm{Fe}^{2+}$ は中位の硬い酸であるので $\mathrm{I}^{-}$が安 定な結合を作る可能性があり，これによって $\mathrm{Fe}^{2+}-\mathrm{O}^{2-}$ の 結合を切断し，不動態皮膜を溶解できる。こうして不動 態皮膜に侵入した高い濃度の $\mathrm{I}^{-}$と $\mathrm{Cl}^{-}$の協同作用によっ て低い $E_{\mathrm{pit}}$ においてピットを発生し，不動態皮膜が破壞 されたと考えている.

ピット発生後, $i=10 \mu \mathrm{Acm}^{-2}$ に達したc'点において 電位走査を逆転すると，ピット内に生成した裸の $\mathrm{Fe}$ 表 面に軟らかい塩基の吸着インヒビターである $\mathrm{I}^{-}$が吸着 し, 酸性水溶液中の $\mathrm{Fe}$ 腐食のアノード反応を抑制した。 このため, c'点以降の $i$ は大きく増加しなかった. その 後, 電位の降下によってピーク (d’点)を経て $\mathrm{e}^{\prime}$ 点におい て $E_{\text {rep }}$ が得られた， $E_{\text {rep }}{ }^{0}<E_{\text {rep }}$ であることから，ピット 成長を抑制したことになる。これはピット成長過程のア ノード溶解を I-の吸着によって抑制したものである。こ うして軟らかい塩基の吸着インヒビターはピット発生を 抑制できないがピット成長を抑制できる。

\section{$3.3 E_{\text {rep }}$ におけるI゙によって抑制されたピット部の EPMA $^{8)}$}

$\mathrm{I}^{-}$によるピット成長に対する抑制作用を調べるため に, $E_{\text {rep }}$ におけるピット部を含む不動態化 $\mathrm{Fe}$ 表面の EPMA を行った. Fig. 2 は $0.03 \mathrm{M}$ の $\mathrm{I}^{-}$を添加した 0.05 $\mathrm{M} \mathrm{Cl}^{-}$ホウ酸塩緩衝溶液中で $E_{\text {rep }}$ に到達した直後の不動 態化 Fe 表面の SEM 写真とピット部を通る $\mathrm{AB}$ 間の線分 析の結果である。直径約 $10 \mu \mathrm{m}$ のピットが生成し, ピ ット内の $\mathrm{Fe}$ の X 線強度が周辺部よりも高く, 裸の $\mathrm{Fe}$ 表面がピット内に露出していることを示唆した。このピ ット内に $\mathrm{I}$ と $\mathrm{Cl}$ の存在が認められ, $\mathrm{I}^{-}$がピットの中心部 でやや増加し $\mathrm{Cl}^{-}$が減少していた。 ピット中心部におけ る $\mathrm{I}^{-}$の増加はピット部の高低差による影響が含まれてい るかもしれない. $\mathrm{Cl}^{-} よ り も$ 軟らかい塩基である $\mathrm{I}^{-}$は軟 らかい酸である裸の $\mathrm{Fe}$ 表面に良く吸着し, $\mathrm{Cl}^{-}$が表面か ら脱着したことを示した。こうして，ピット内の裸の

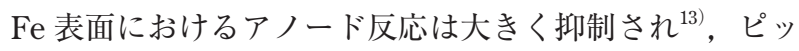
ト内の腐食が著しく低下したものである．また，不動態 皮膜の部分に $\mathrm{I}^{-}$や $\mathrm{Cl}^{-}$がピット部分よりも多く存在する のは，ピット部分では $\mathrm{Fe}$ 表面への吸着であるのに，不 動態皮膜中では侵入によるためと考えられる。なお， $\mathrm{Cl}^{-}$ のみを添加した場合の $E_{\mathrm{pit}}$ 直後の EPMAによると, ピッ 卜内部において Fe の X 線強度の増加と本報よりも少し 高い $\mathrm{Cl}$ の X 線強度が得られている ${ }^{10)}$.

この結果から見ると, $E_{\text {rep }}$ において $i$ はほほ $0 \mu \mathrm{Acm}^{-2}$ になったが, ピット内部に不動態皮膜が再生されたわけ ではない. $E_{\mathrm{rep}}$ に到達した後溶液中に長時間おけばピッ 卜内の溶液が交換して，ホウ酸塩緩衝溶液や $\mathrm{O}_{2}$ によっ て不動態皮膜が再生されると思われるが, 短時間ではピ ット内部は主として I-の吸着によって抑制された状態で あった。

Fig. 2 の SEM 写真で見られるピット部以外の不動態 皮膜で覆われた部分には $\mathrm{I}^{-} と \mathrm{Cl}^{-}$が存在し，不動態皮膜

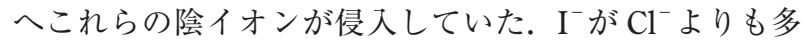
く存在し, より軟らかい塩基である $\mathrm{I}^{-}$が不動態皮膜中の $\mathrm{Fe}^{3+}$ や $\mathrm{Fe}^{2+}$ によって拘束されないために, 容易に侵入す ることが実証された.

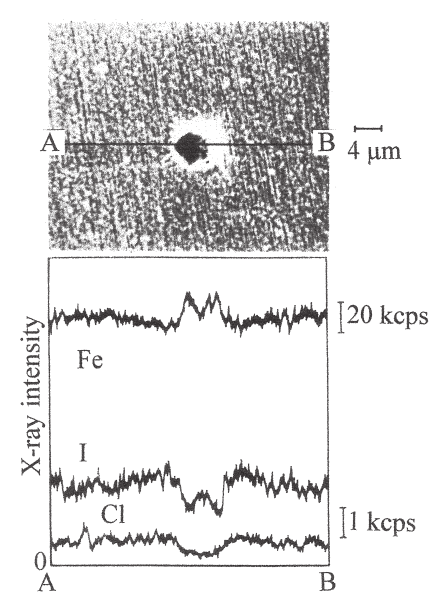

Fig. 2 A SEM photograph and line analyses of $\mathrm{Fe}$, I and $\mathrm{Cl}$ between $\mathrm{A}$ and $\mathrm{B}$ for the passivated Fe electrode surface at $E_{\text {rep }}$ in the borate buffer solution containing $0.05 \mathrm{M} \mathrm{Cl}^{-}$ plus $0.03 \mathrm{M} \mathrm{I}^{-8)}$. 


\section{4. 結}

$\mathrm{Cl}^{-}$を含むホウ酸塩緩衝溶液中における不動皮膜破壊 に対する $\mathrm{I}^{-}$添加の影響について考察した．軟らかい塩基 に分類される $\mathrm{I}^{-}$と $\mathrm{Cl}^{-}$は硬い酸である $\mathrm{Fe}^{3+}$ と安定な酸塩 基結合を作らないために皮膜内部に侵入しやすく， $\mathrm{I}^{-}$は $\mathrm{Fe}^{3+}$ を還元して $\mathrm{Fe}^{2+}$ を生成させることでピット発生を促 進する。このため, 孔食電位は低下し, 抑制作用は見ら れない. ピット発生後, ピット内溶液の $\mathrm{pH}$ 低下によっ て生成した裸の $\mathrm{Fe}$ 表面に $\mathrm{I}^{-}$が吸着してピット成長を抑 制し, 再不動態化電位を上昇させた。再不動態化電位に おける $\mathrm{Fe}$ 表面の EPMA の結果, ピット内部に裸の $\mathrm{Fe}$ 表面が存在し，そこに $\mathrm{I}^{-}$が吸着し $\mathrm{Cl}^{-}$を脱着させた。こ のため, ピット内の $\mathrm{Fe}$ 腐食のアノード反応は著しく抑 制され，再不動態化したように見せた，再不動態化電位 に到達した直後におけるピット内は不動態皮膜が再生さ れたのではなく, 主に $\mathrm{I}^{-}$が吸着した裸の $\mathrm{Fe}$ 表面であっ た.

\section{参 考 文 献}

1) K. Aramaki, Zairyo-to-Kankyo, 62, 501 (2013).

2) K. Aramaki, Zairyo-to-Kankyo, 63, 12 (2014).

3) G. R. Pearson, J. Am. Chem. Soc., 85, 3533 (1963).

4) K. Aramaki, Proc. 5th European Symposium on Corrosion Inhibitors, vol. 1, p. 267, Università Degli Studi di Ferrara, Ferrara (1980).

5) O. M. Magnussen, Encyclopedia of Electrochemistry, vol. 4, M. Stratmann and G. S. Frankel, Eds., p. 445, Wiley-VCH Verlag GmbH \& Co., Weinheim (2003).

6) K. Aramaki, Zairyo-to-Kankyo, 63, 417 (2014).

7) K. Aramaki, M. Mizoguchi and H. Nishihara, J. Electrochem. Soc., 138, 394 (1991).

8) M. Yamaguchi, H. Nishihara and K. Aramaki, Corros. Sci., 37, 571 (1995)

9) V. Jovancicevic, J. O'M. Bockris, J. L. Carbajal, P. Zelenay and T. Mizuno, J. Electrochem. Soc., 113, 2219 (1986).

10) M. Yamaguchi, H. Nishihara and K. Aramaki, Corros. Sci., 36, 241 (1994).

11) Dictionary of Inorganic Compounds, vol. 3, p. 3271, J. E. Macintyre, Ed., Chapman \& Hall, London (1992).

12) T. Kawai, H. Nishihara and K. Aramaki, Corros. Sci., 38, 225 (1996).

13) K. Aramaki, Zairyo-to-Kankyo, 62, 334 (2013).

(Manuscript received February, 12, 2015; in final form April 17, 2015)

\section{要 旨}

最近, $\mathrm{Fe}$ 不動態皮膜の破壊を種々の陰イオン溶液中に扔ける破壊までに要する時間 $t_{\mathrm{bd}}$ と X 線光電子分 光法を用いた不動態皮膜中への陰イオンの侵入を測定することで研究した．その結果を硬いおよび軟らか い酸塩基の法則 ( $\mathrm{HSAB}$ 則) に基づいて検討した，以前の研究において， $\mathrm{Cl}^{-}$を含むホウ酸塩緩衝溶液中に おける不動態化 $\mathrm{Fe}$ 電極の孔食電位と再不動態化電位を測定した。ピット発生とピット成長に及ぼす添加 した I'の影響を電子線プローブ微小分析法を用い HSAB 則に基づいて考察した，本報では，以前の研究結 果を最近の考察からより詳細に説明する。

キーワード 鉄, 不動態皮膜破壞, 孔食電位, 再不動態化電位, 塩化物イオン, ヨウ化物イオン, 電 子線プローブ微小分析法 